\title{
Whey protein-based films incorporated with oregano essential oil
}

\author{
Sandra Prestes Lessa Fernandes Oliveira ${ }^{1}$, Larissa Canhadas Bertan², \\ Christiane Maciel Vasconcellos Barros De Rensis ${ }^{1}$, Ana Paula Bilck ${ }^{1}$ and Priscila Cristina Bizam Vianna ${ }^{3 *}$
}
'Programa de Pós-graduação em Ciência e Tecnologia de Leite e Derivados, Universidade Norte do Paraná - UNOPAR, Londrina, PR, Brazil

${ }^{2}$ Universidade Federal da Fronteira Sul - UFFS, Laranjeiras do Sul, PR, Brazil

${ }^{3}$ Departamento de Engenharia de Alimentos, Instituto de Ciências Tecnológicas e Exatas, Universidade Federal do Triângulo Mineiro - UFTM, Uberaba, MG, Brazil

*priscila.vianna@uftm.edu.br

\begin{abstract}
This study aimed to prepare whey protein-based films incorporated with oregano essential oil at different concentrations, and evaluate their properties and antimicrobial activity. Films were more flexible with increasing the concentration of oregano oil and water vapor permeability was higher in the films with oregano oil. Increasing the concentration of essential oil decreased the water solubility. The solubility of control film and film with $1.5 \%$ oregano oil was 20.2 and $14.0 \%$, respectively. The addition of $1 \%$ of oregano oil improved the resistance of the films. The tensile strength for the control film was $66.0 \mathrm{MPa}$, while for the film with $1 \%$ of oregano oil was $108.7 \mathrm{MPa}$. Films containing $1.5 \%$ oregano oil showed higher antimicrobial activity. The zone of inhibition ranged from 0 to $1.7 \mathrm{~cm}$. The results showed that the whey protein-based films incorporated with oregano essential oil has potential application as active packaging.
\end{abstract}

Keywords: active film, whey protein, natural antimicrobial, packaging.

\section{Introduction}

Edible coatings and films of various thickness consist of edible materials (proteins, lipids, carbohydrates) applied to the surface of food to improve the appearance and food preservation $^{[1]}$. In recent years, there has been considerable interest in its use as food packaging, instead of the traditional plastic films. Edible coatings are defined as a thin layer of edible material applied directly to the surface of food, usually by immersion or aspersion, while edible films are pre-formed in molds, dried and applied to food ${ }^{[1-3]}$. The purpose of the use of films and coatings is to inhibit the migration of moisture, oxygen, carbon dioxide, flavors, and lipids, and carry food ingredients (antioxidants, antimicrobial agents, flavorings), and/or improve the mechanical and handling characteristics of the product. In some cases, the films and edible/biodegradable coatings can replace synthetic packaging ${ }^{[2]}$.

Whey is a by-product of the cheese industry with high nutritional and functional value. When properly processed either as protein isolate or as concentrate, it consists of an excellent ingredient for the production of various processed foods. For a long time, whey had been considered as a waste by-product with no commercial value, which was discharged into watercourses causing serious environmental problems ${ }^{[4,5]}$ or even incorporated into animal feed. This approach, however, was disregarded due to the excellent nutritional and functional properties of whey, and the production of whey protein-based films has been studied for application as alternative packaging ${ }^{[6]}$.

The gelation phenomenon required for the formation of a film or coating, is achieved by physical and chemical interactions between the whey protein molecules. Despite the destabilization of whey protein can be achieved by various processes heating is the most used form. These processes induce the breakdown of the structure of the whey proteins, resulting in aggregation and gel formation. The heating modifies the three dimensional structure of proteins by exposure of the -SH groups and hydrophobic groups promoting intramolecular bonds and S-S hydrophobic interactions during drying of the films/coatings. In the absence of heat treatment, the films become brittle and fragile after drying ${ }^{[7,8]}$.

Milk protein based films have good mechanical properties, and act as excellent barriers to lipid, oxygen and aromas. However, they do not have an ideal water vapor barrier due to its hydrophilic nature ${ }^{[9-11]}$. When properly processed, whey proteins produced flexible, transparent, and odorless films ${ }^{[12]}$. The application of these films can be improved by adding antimicrobial agents to ensure a more effective conservation of the packaged or coated food ${ }^{[13-15]}$.

Antimicrobial agents from natural or synthetic sources have been explored with satisfactory results regarding the growth inhibition of spoilage and pathogenic microorganisms. Among the most studied antimicrobial agents are the organic acids and their salts (propionic, benzoic, sorbic), bacteriocins (nisin), enzymes (lysozyme, glucose oxidase), polysaccharides (chitosan), and natural plant extracts (essential oil from oregano, pepper, rosemary) ${ }^{[15-17]}$. Antimicrobial substances can be added to the polymers by melting or solubilization of the compound within the matrix. Once these substances 
are heat sensitive, the solubilization method is the most suitable to incorporate them into the biopolymer matrix ${ }^{[13]}$.

The oregano essential oil has emerged as the most studied essential oil with applications in food, and the Origanum vulgare sp has been one of the most studied for its antioxidant and antimicrobial activities ${ }^{[18-20]}$. This essential oil has high content of phenolic compounds responsible for its antimicrobial and antioxidant activity. Among the components, both carvacrol and thymol stand out as active ingredients ${ }^{[21]}$. The hydroxyl groups in this phenolic compounds are the cause of inhibitory action as these groups can interact with the cell membrane of bacteria to disrupt membrane structures and cause the leakage of cellular components. There are suggestions that the active groups of carvacrol and thymol promotes the delocalization of electrons which then act as proton exchangers and reduce the gradient across the cytoplasmic membrane of bacterial cells. This will cause the collapse of the proton motive force and depletion of the ATP pool and ultimately leading to cell death. These phenolic groups can further bind the active site of enzymes by altering the cell metabolism of microorganisms ${ }^{[22]}$. Sahin et al. ${ }^{[23]}$ reported the antimicrobial activity of oregano essential oil against 10 bacteria strains and 15 fungi and yeast species.

Oregano essential oil has been used in active films with different composition for use in foods. Pelissari et al. ${ }^{[2]}$ observed inhibition of Bacillus cereus, Escherichia coli, Salmonella enteritidis and Staphylococcus aureus in starch-chitosan based films incorporated with $0.1 \%, 0.5 \%$ and $1.0 \%$ of oregano essential oil. Furthermore, the oil addition has improved the water vapor permeability and led to formation of more flexible films. Oussalah et al. ${ }^{[25]}$ produced milk protein based films incorporated with oregano and pepper oil for beef preservation. The films incorporated with oregano oil stabilized lipid oxidation in beef during 7 days of storage and proved effective against $E$. coli O157: H7 and Pseudomonas spp strains.

Seydim and Sarikus ${ }^{[10]}$ evaluated the antimicrobial properties of whey protein-based films incorporated with different concentrations of essential oil extracted from oregano, rosemary and garlic. Films containing 3 and $4 \%$ oregano and garlic essential oils were effective against $S$. aureus, $S$. enteretidis, L. monocytogenes, E. coli and L. plantarum. In contrast, films incorporated with rosemary oil did not exhibit antimicrobial activity. The authors highlighted the potential application of the active films in packaging of cheese slices.

Thus, the whey protein-based films incorporated with essential oils with antimicrobial properties can be used as an active packaging technology applied to dairy products such as processed and sliced cheese to inhibit the growth of pathogenic and spoilage microorganisms, and simultaneously increase the shelf life of these products. The aim of this study was to produce and evaluate the effects of the incorporation of oregano essential oil on the water vapor permeability, solubility, tensile strength and antimicrobial activity of whey protein-based films.

\section{Materials and Methods}

\subsection{Materials}

The films were produced with whey protein isolate (WPI 95\% Bipro, Davisco, USA). Glycerol (Synth, Brazil) was added to the formulation as plasticizer. Oregano essential oil (Origanum vulgare) was acquired from Ferquima Indústria e Comércio Ltda (São Paulo, Brazil). The essential oil met all the required specifications in relation to its quality control as the certificate of analysis provided by the supplier.

\subsection{Films manufacture}

Four types of films were made: control film, composed of whey protein isolate and glycerol; and whey protein-based films incorporated with oregano essential oil at three different concentrations: $0.5 \%, 1.0 \%$ and $1.5 \%(\mathrm{v} / \mathrm{v})$. The concentrations of essential oil were defined according to literature ${ }^{[10]}$.

The films were produced by casting according to the methodology described by Yoshida and Antunes ${ }^{[26]}$. The whey protein isolate ( $7.0 \%$, dry weight basis) was dispersed in distilled water, followed by agitation on a magnetic stirrer until complete solubilization. Then, $3.0 \%$ glycerol $(\mathrm{w} / \mathrm{w})$ was added and the film forming solution was heated to $90^{\circ} \mathrm{C} / 30$ minutes in a water bath to denature the whey proteins. After cooling to room temperature $\left(25^{\circ} \mathrm{C}\right)$, the $\mathrm{pH}$ of the solution was adjusted to 7.0 using $\mathrm{NaOH} 0.1 \mathrm{M}$. An aliquot of $10 \mathrm{~mL}$ was poured into $9 \mathrm{~cm}$ Petri dishes slightly greased with sunflower oil, and left to dry at $24^{\circ} \mathrm{C} / 24$ hours, on the laboratory bench. After drying, the films were removed from the dishes with a spatula, stored in desiccators with 53\% relative humidity (magnesium nitrate saturated solution), and separated by sheets of tissue paper.

The films containing the antimicrobial agent were produced following the same procedure used for the control film, differing only by the addition of oregano essential oil (OEO) at concentrations of $0.5 \%, 1.0 \%$ and $1.5 \%(\mathrm{v} / \mathrm{v})$ to their respective film forming solution prior to heat treatment at $90{ }^{\circ} \mathrm{C} / 30$ minutes, to facilitate their incorporation into the protein matrix. The drying and conditioning of the films was the same of the control film.

\subsection{Films characterization}

Before the characterization analyses, all dried films were stored in desiccators at $25{ }^{\circ} \mathrm{C}$ and $53 \%$ relative humidity $(\mathrm{RH})$ for 48 hours. The films were characterized for visual appearance, thickness, water vapor barrier properties, water solubility and tensile strength.

The films were evaluated for visual and tactile aspect aimed to select only the homogeneous films (without the presence of insoluble particles, bubbles and uniform color), with no breaks or frangible areas to the analytical determinations.

The thickness of the films was determined using a digital micrometer with a resolution of $0.001 \mathrm{~mm}$ (Mitutoyo MDC-25M, Kanagawa, Japan) and was calculated as the mean of ten measurements of the film area.

The water vapor permeability (WVP) was determined gravimetrically at $25{ }^{\circ} \mathrm{C}$ according to standard method E-96-95 ASTM ${ }^{[27]}$. The best films previously selected by visual 
and tactile aspect were cut into discs with $9 \mathrm{~cm}$ in diameter and set out in the circular opening of the capsule to ensure moisture migration exclusively through the film. The interior of the capsule was filled with $15 \mathrm{~g}$ calcium chloride, and the system was placed into a desiccator containing a saturated solution of sodium chloride, corresponding to RH 75\%. The test was carried out in triplicate for each formulation with $\mathrm{RH}$ gradient $(0-75 \%)$ at $25^{\circ} \mathrm{C}$. Water vapor transport was determined from the weight gain of the calcium chloride measured every 24 hours for 7 days. The relative water vapor permeability $(R W V P)$ was calculated as follows:

$$
R W V P=(m / t) \times(1 / A)
$$

where $A$ is the permeation area of the film $\left(\mathrm{m}^{2}\right), m$ is the mass of vapor permeated ( $\mathrm{g}$ ) and $t$ is the time (days).

The water vapor permeability $(W V P)$ was calculated by the equation:

$$
W V P=(R W V P \times e) /\left(p_{s} x\left(R H_{1}-R H_{2}\right)\right)
$$

where $e$ is the average film thickness $(\mathrm{m}), p_{S}$ is the saturated vapor pressure at the test temperature $(\mathrm{Pa}), R H_{1}$ is the relative humidity inside the desiccator and $\mathrm{RH}_{2}$ is the relative humidity inside the capsule.

The water solubility of the films was determined according to the method proposed by Gontard et al. ${ }^{[28]}$, in triplicate. The samples were cut into discs of $2.5 \mathrm{~cm}$ in diameter and dried in an oven at $105^{\circ} \mathrm{C}$ for 24 hours to obtain the initial dry mass. The dried samples were immersed in a beaker containing $50 \mathrm{~mL}$ distilled water and kept under slow stirring (100 rpm) for 24 hours at $25{ }^{\circ} \mathrm{C}$ using a magnetic stirrer. After this period, the samples were subjected again to drying at $105^{\circ} \mathrm{C}$ for 24 hours to obtain final dry mass. The water solubility was calculated using the following equation:

$$
S O L=\left(M_{i}-M_{f}\right) / M_{i} \times 100
$$

where: $S O L$ is the solubilized mass as a function of the initial dry mass (\%), $M_{I}$ is the initial dry mass (g) and $M_{F}$ is the final dry mass after solubilization $(\mathrm{g})$.

The tensile strength $(T S)$ was measured using a TA.XT2 Texture Analyzer (Stable Micro System, Hasleme, England) according to the method of the American Society for Testing and Materials ${ }^{[29]}$. The measurements were carried out at $25^{\circ} \mathrm{C}$. The samples were cut into $80 \mathrm{~mm}$ long $\times 25 \mathrm{~mm}$ wide strips, and was adjusted to the grip device with a distance of $30 \mathrm{~mm}$. The test speed was $1 \mathrm{~mm} / \mathrm{s}$. Ten replicates of each formulation were performed. The ultimate tensile strength was calculated according to the equation:

$$
T S=F_{m} / A
$$

where $T S$ is the ultimate tensile strength at break (MPa), $F_{M}$ is the maximum force at break of the film $(\mathrm{N})$, and $A$ is the cross sectional area of the film $\left(\mathrm{m}^{2}\right)$.

\subsection{Antimicrobial effectiveness of the films by agar diffusion method}

To determine the antimicrobial effectiveness of the whey protein-based films, a lyophilized culture of Penicillium commune (CCT 4685) donated by André Tosello Foundation (Campinas, São Paulo, Brazil) was used. The reactivation of lyophilized cells of Penicillium commune was performed according to the following procedure: the rehydration was carried out for 30 minutes in sterile distilled water, and the entire contents of the vial were poured onto a plate containing Potato Dextrose Agar (PDA, Difco Laboratories), which was incubated at $25^{\circ} \mathrm{C} / 5$ days. After growth, the colonies were transferred to tubes containing PDA agar, which were incubated at $25^{\circ} \mathrm{C} / 5$ days and then kept under refrigeration $\left(7^{\circ} \mathrm{C}\right)$. These tubes contained the inoculum to be used in the diffusion tests.

For the diffusion test, the colonies were collected, with a handle, from the tubes containing the inoculum and transferred to an erlenmeyer having $50 \mathrm{~mL} 0.1 \%$ peptone water with $0.1 \%$ Tween 80 . The suspension was stirred for $1 \mathrm{~min}$ and filtered with the aid of sterile gauze. From this initial inoculum, decimal dilutions were performed, and the suspension for the diffusion test was selected according to the growth characteristics of the target microorganism.

The agar diffusion test was used to qualitatively evaluate the antimicrobial activity of the films according to Pelissari et al. ${ }^{[24]}$ with modifications. The active films were placed on the surface of the solidified PDA, together with $0.1 \mathrm{~mL}$ suspension of Penicillium commune seeded with Drigalski handle. Circular cuts $(2.5 \mathrm{~cm}$ in diameter) of the control films and films incorporated with $0.5 \%, 1.0 \%$ and $1.5 \%$ oregano essential oil were exposed to UV light for $15 \mathrm{~min}$ and placed aseptically onto the surface of solidified medium inoculated with the target microorganism. The plates were incubated at $25^{\circ} \mathrm{C} / 5$ days. The efficiency of the antimicrobial agent was evaluated by the formation of halo around the disks and by quantification of colony-forming units $\left(\mathrm{CFU} \mathrm{mL} \mathrm{m}^{-1}\right)$. All experiments were performed in triplicate.

\subsection{Statistical analysis}

The effect of the addition of oregano essential oil on the characteristics and antimicrobial activity of edible films was assessed by analysis of variance and Tukey's test at 5\% significance level. Statistical analysis was performed using the Statistica software (version 8.0, 2007; Stat-Soft Inc., Tulsa, OK).

\section{Results and Discussions}

\subsection{Films characterization}

The whey protein-based films with and without addition of oregano essential oil (OEO) at different concentrations were, in general, homogeneous, transparent, and yellowish. The films incorporated with higher concentrations of essential oil $(1.0 \%$ and $1.5 \%)$ were visually more malleable than the others were. Ramos et al. ${ }^{[8]}$ studied films produced from whey protein isolate or protein concentrate, and observed similar visual characteristics to those found in this study. 
Table 1 shows results for thickness, water vapor permeability, water solubility and tensile strength of active whey protein films.

Film thickness ranged from $0.013 \mathrm{~mm}$ to $0.015 \mathrm{~mm}$ (Table 1) and the control film showed lower thickness than the films with $0.5 \%$ and $1.0 \%$ essential oil. The difference between the thicknesses of the control as compared with the films incorporated with $0.5 \%$ and $1.0 \%$ essential oil could have been caused by lack of accuracy in measuring the volumes of filmogenic solution added to the Petri dishes. Bertan et al. ${ }^{[30]}$ observed that the addition of hydrophobic substances promoted an increase of the biofilm thickness, being necessary to use different ratios for each formulation aimed at controlling thickness for the repeatability of the measurements and validity of comparisons between properties. In the case of this study, it can be considered that the percentage of the hydrophobic substance (oregano essential oil) was too low to cause such variation.

The water vapor permeability (WVP) was significantly higher in the films containing the oregano essential oil (Table 1), contrary to what is expected for films made with hydrophobic substances. The incorporation of lipids in the protein film matrix reduces the interaction for water molecules, reducing the water vapor permeability of the films ${ }^{[26]}$. Probably the oregano essential oil could not bind chemically to the protein matrix, leaving empty spaces through which water could permeate, causing a higher WVP in active films.

Gontard et al. ${ }^{[28]}$, who evaluated the incorporation of hydrophobic substances to wheat gluten based films, found similar results. The authors observed that the hydrophobic molecules having substantially spherical large size, when used in formulations of composite films, can lead to the occurrence of cracks and preferred channels through which water can diffuse, resulting in higher water vapor permeability.

Despite the low concentrations of oregano essential oil used in this study, the increase of WVP could have been caused by the incompatibility of oil with the whey protein isolate, resulting in a disruption of the film matrix. In general, the films were very poorly permeable to water vapor, regardless of the addition of oregano oil. The values found in the present study were lower than those observed by other authors. Yoshida and Antunes ${ }^{[26]}$ found mean WVP values of 0.3023 and $0.2680 \mathrm{~g} \mathrm{~mm} \mathrm{~h}^{-1} \mathrm{~m}^{-2} \mathrm{kPa}^{-1}$ for control whey protein-based films and whey protein-based films emulsified with stearic acid, respectively. WVP values of 15.013 and $13.526 \mathrm{~g} \mathrm{~mm} \mathrm{~h}^{-1} \mathrm{~m}^{-2} \mathrm{kPa}^{-1}$ were found by Mei and $\mathrm{Zhao}^{[31]}$ for control whey protein-based films and films incorporated with $0.2 \% \alpha$-tocopherol acetate.

The control film and those containing $1 \%$ essential oil had significantly higher solubility than the film containing
$1.5 \%$ oil. No differences among the other films were observed (Table 1). The lower solubility of the film incorporated with $1.5 \%$ essential oil can be explained by its higher hydrophobic character.

All films remained intact after the solubility test, indicating the formation of a stable network. McHugh and Krochta $^{[32]}$, Fairley et al. ${ }^{[33]}$ and Galietta et al. ${ }^{[34]}$ stated that whey protein-based films are partly water insoluble due to the presence of intermolecular disulfide bonds, making them resistant to solubilization in aqueous buffers. The presence of this type of binding in the matrix pores may be trapped the oregano oil, thus decreasing water solubility, which was intensified by both the higher oil concentration and the hydrophobic nature of the compound. The water solubility of the protein appears to be related to its hydrophilicity and the structure of the resulting protein matrix. The incorporation of a hydrophobic compound in the formulation of protein films reduces the ability of the film-forming matrix for bonding with water molecules ${ }^{[32]}$. According to Bertan ${ }^{[35]}$, the water solubility of the films is directly related to its components, i.e., the hydrophilicity/hydrophobicity, and structure.

The control film showed less resistance when compared to the others (Table 1). Oregano oil has improved the resistance of the films. Among the different oil concentrations, the film incorporated with $1 \%$ essential oil had significantly higher resistance than the other films. The heat used for the preparation of the films caused denaturation of whey proteins and exposure of sulfhydryl groups, resulting in an increase of S-S covalent bonds in the films, featuring the formation of stable films capable to extend ${ }^{[7,33]}$.

Yoshida $^{[6]}$ found that the tensile strength was higher for films containing high concentrations of whey protein $(5.5 \%$ to $7.5 \%)$, resulting in an increase in tensile strength of about $0.4493 \mathrm{MPa}$, which is related to the increased number of S-S covalent bonds in the film matrix, due to the larger amount of sulfhydryl groups on the protein surface.

The incorporation of oregano oil in the film forming solution caused the destabilization of the matrix, resulting in increased WVP, and the bonds formed due to protein denaturation have trapped the oil, thus increasing hydrophobicity of the matrix. The "spacing" caused by the oil may have promoted most interactions between the side groups of the protein chain, resulting in greater interactions and consequently greater tensile strength. The increase in concentration from $1 \%$ to $1.5 \%$ oil resulted in a decrease in the tensile strength from 108.7 $\mathrm{MPa}$ to $91.5 \mathrm{MPa}$, probably due to the plasticizing effect caused by the "excess" of oil or the lubricating effect of the matrix. Pelissari et al. ${ }^{[24]}$ also observed a reduction in $T S$ in starch-chitosan based films incorporated with $0.1 \%$, $0.5 \%$ and $1.0 \%$ oregano essential oil, and attributed the results to the plasticizing capacity of oregano oil.

Table 1. Mean values of thickness, water vapor permeability, water solubility and tensile strength (TS) of the whey protein-based films.

\begin{tabular}{|c|c|c|c|c|}
\hline Treatments & $\begin{array}{c}\text { Thickness } \\
\text { (mm) }\end{array}$ & $\begin{array}{c}\text { WVP } \\
\left(\mathrm{g} \mathrm{mm} \mathrm{m}^{-2} \text { day }^{-1} \mathrm{kPa}^{-1}\right)\end{array}$ & $\begin{array}{c}\text { Solubility } \\
(\%)\end{array}$ & $\begin{array}{c}\text { TS } \\
\text { (MPa) }\end{array}$ \\
\hline Control & $0.01342 \pm 0.002^{\mathrm{b}}$ & $0.00070 \pm 0.00007^{\mathrm{a}}$ & $20 \pm 2^{\mathrm{a}}$ & $66 \pm 5^{\mathrm{c}}$ \\
\hline $0.5 \% \mathrm{OEO}^{1}$ & $0.01542 \pm 0.001^{\mathrm{a}}$ & $0.0010 \pm 0.0004^{\mathrm{b}}$ & $17 \pm 2^{\mathrm{ab}}$ & $96 \pm 3^{b}$ \\
\hline $1.0 \% \mathrm{OEO}$ & $0.01500 \pm 0.001^{\mathrm{a}}$ & $0.0011 \pm 0.0001^{\mathrm{b}}$ & $17 \pm 1^{\mathrm{a}}$ & $109 \pm 7^{\mathrm{a}}$ \\
\hline $1.5 \% \mathrm{OEO}$ & $0.01475 \pm 0.001^{\mathrm{ab}}$ & $0.00100 \pm 0.00007^{\mathrm{b}}$ & $14 \pm 3^{b}$ & $92 \pm 8^{b}$ \\
\hline
\end{tabular}

'OEO: oregano essential oil. Averages with different letters in the same column differ significantly $(P<0.05)$. 
Table 2. Microbiological efficiency of the active films by diffusion test against Penicillium commune.

\begin{tabular}{ccc}
\hline Treatments & CFU mL $\mathbf{~}^{-1}$ & Diameter of zone of inhibition (cm) \\
\hline Control & $5.13 \times 10^{5 \mathrm{a}}$ & $0.00 \pm 0^{\mathrm{b}}$ \\
$0.5 \% \mathrm{OEO}^{1}$ & $3.17 \times 10^{5 \mathrm{a}}$ & $0.07 \pm 0.10^{\mathrm{b}}$ \\
$1.0 \%$ OEO & $3.14 \times 10^{5 \mathrm{a}}$ & $1.3 \pm 0.8^{\mathrm{a}}$ \\
$1.5 \%$ OEO & $1.98 \times 10^{5 \mathrm{a}}$ & $1.7 \pm 0.5^{\mathrm{a}}$ \\
\hline
\end{tabular}

${ }^{1} \mathrm{OEO}$ : oregano essential oil. Averages with different letters in the same column differ significantly $(P<0.05)$.
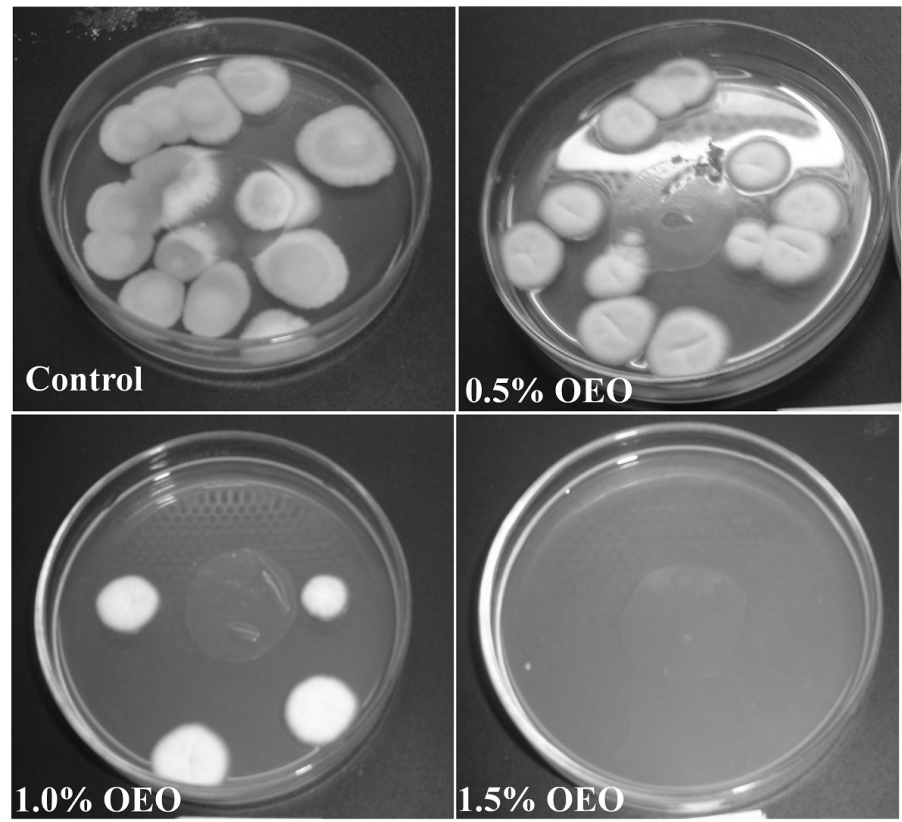

Figure 1. Diffusion test for whey protein-based films incorporated with different concentrations of oregano essential oil (OEO) against Penicillium commune.

\subsection{Diffusion test}

The results of the diffusion test are presented in Table 2. The average concentration of the Penicillium commune suspension was $5.5 \times 10^{5} \mathrm{CFU} \mathrm{mL}^{-1}$. The addition of oregano essential oil caused no significant difference in the number of colony-forming units, which was in the order of $10^{5} \mathrm{CFU} \mathrm{mL} \mathrm{m}^{-1}$ for all treatments.

The zone of inhibition was measured as the shortest distance between the film and the nearest colony-forming unit. The halo diameter varied from 0 to $1.7 \mathrm{~cm}$. A significant increase in the halo diameter with increasing concentration of oregano (Figure 1) oil was observed. Films containing $1.0 \%$ and $1.5 \%$ oregano oil showed significantly higher halos than both the control film and that containing $0.5 \%$ oil. No significant difference was observed between the halos of the films with 1.0 and $1.5 \%$ oregano oil.

Oussalah et al. ${ }^{[25]}$ showed that $1 \%$ oregano essential oil incorporated into a calcium caseinate and whey protein isolate edible films containing carboxymethyl cellulose showed inhibitory effect against E. coli O157: H7 and Pseudomonas spp. on the surface of beefsteaks. This study suggests that $2 \%$ oregano essential oil in WPI based films was the minimum concentration with inhibitory effect against $S$. aureus, S. enteritidis, L. monocytogenes, L. plantarum e E. coli O157: H7.
Seydim and Sarikus ${ }^{[10]}$ performed the halo test in whey protein isolate edible films containing oregano essential oil against different microorganisms. Unlike the results observed in this study, the authors found no antimicrobial effect in the films with $1 \%$ oregano oil for the target microorganisms. The minimum concentration required for inhibition was $2 \%$. The largest zone of inhibition was observed at concentration of $4 \%$ oregano oil against $S$. aureus, Salmonella enteritidis and Listeria monocytogenes.

Pelissari et al. ${ }^{[24]}$ studied starch-chitosan based films incorporated with oregano essential oil at different concentrations $(0 \%, 0.1 \%, 0.5 \%$, and $1.0 \%)$, and found an increase of the zones of inhibition with increasing oil concentrations for the different microorganisms. The largest zones of inhibition were observed for Gram-positive bacteria (B. cereus and $S$. aureus) when compared with Gram-negative bacteria (S. enteritidis e E. coli).

\section{Conclusions}

Our results indicate that whey protein isolate is a good matrix for the production of biodegradable flexible films, and the addition of oregano essential oil, even in small quantities positively affected the characteristics of the films. Low vapor permeability values and low water 
solubility of films with oregano essential oil makes it can be used in both dry foods and in products with a greater water activity. The addition of oregano oil also allowed the production of more flexible films and more resistant at break, particularly at a concentration of $1.0 \%$. In addition, the active films exhibited antimicrobial activity against Penicillium commune at concentrations of $1.0 \%$ and $1.5 \%$. Based on these results it can be concluded that the films added with $1.0 \%$ of oregano essential oil presented the best characteristics. Thus, the whey protein isolate-based films incorporated with oregano essential oil has potential application as active food packaging, which may extend the shelf life of food products. Due to their characteristic aroma, it is recommended to use these active films as an alternative to commercial coatings for cheeses.

\section{Acknowledgements}

The authors are grateful to the Fundação Nacional de Desenvolvimento do Ensino Superior Particular (FUNADESP, Brasília, DF, Brazil) for the financial support and Fundação Tropical de Pesquisas e Tecnologia André Tosello for donating the strain of Penicillium commune.

\section{References}

1. Falguera, V., Quintero, J. P., Jiménez, A., Muñoz, J. A., \& Ibarz, A. (2011). Edible films and coatings: structures, active functions and trends in their use. Trends in Food Science \& Technology, 22(6), 292-303. http://dx.doi.org/10.1016/j. tifs.2011.02.004.

2. Krochta, J. M., \& De Mulder-Johnston, C. (1997). Edible and biodegradable polymer films: challenges and opportunities. Food Technology, 51(2), 61-74. Retrieved in 07 March 2017, from http://agris.fao.org/agris-search/search.do?recordID=US9729236

3. McHugh, T. H., \& Senesi, E. (2000). Apple wraps: a novel method to improve the quality and extend the shelf life of fresh-cut apples. Journal of Food Science, 65(3), 480-485. http://dx.doi.org/10.1111/j.1365-2621.2000.tb16032.x.

4. Morr, C. V., \& Ha, Y. W. (1993). Whey protein concentrates and isolates: processing and functional properties. Critical Reviews in Food Science and Nutrition, 33(6), 431-476. PMid:8216810. http://dx.doi.org/10.1080/10408399309527643.

5. Kim, S.-J., \& Ustunol, Z. (2001). Sensory attributes of whey protein isolate and candellila wax emulsion edible films. Journal of Food Science, 66(6), 909-911. http://dx.doi. org/10.1111/j.1365-2621.2001.tb15195.x.

6. Yoshida, C. M. P. (2002). Aplicação de concentrado proteico de soro de leite bovino na elaboração de filmes comestiveis (Doctoral thesis). Universidade Estadual de Campinas, Campinas.

7. Pérez-Gago, M. B., \& Krochta, J. M. (2002). Formation and properties of whey protein films and coatings. In A. Gennadios (Ed.), Protein-based films and coatings (pp. 159-180). Boca Raton: CRC Press.

8. Ramos, Ó. L., Reinas, I., Silva, S. I., Fernandes, J. C., Cerqueira, M. A., Pereira, R. N., Vicente, A. A., Poças, M. F., Pintado, M. E., \& Malcata, F. X. (2013). Effect of whey protein purity and glycerol content upon physical properties of edible films manufactured therefrom. Food Hydrocolloids, 30(1), 110-122. http://dx.doi.org/10.1016/j.foodhyd.2012.05.001.

9. Khwaldia, K., Perez, C., Banon, S., Desobry, S., \& Hardy, J. (2004). Milk proteins for edible film and coatings. Critical
Reviews in Food Science and Nutrition, 44(4), 239-251. PMid:15462128. http://dx.doi.org/10.1080/10408690490464906.

10. Seydim, A. C., \& Sarikus, G. (2006). Antimicrobial activity of whey protein-based edible films incorporated with oregano, rosemary and garlic essential oils. Food Research International, 39(5), 639-644. http://dx.doi.org/10.1016/j.foodres.2006.01.013.

11. Gounga, M. E., Xu, S. Y., \& Wang, Z. (2007). Whey protein isolate-based edible films as affected by protein concentration, glycerol ratio and pullulan addition in film formation. Journal of Food Engineering, 83(4), 521-530. http://dx.doi.org/10.1016/j. jfoodeng.2007.04.008.

12. Gennadios, A., McHugh, T. H., Weller, C. L., \& Krochta, J. M. (1994). Edible coatings and films based on proteins. In J. M. Krochta, E. A. Baldwin \& M. O. Nisperos-Carriedo (Eds.), Edible coatings and films to improve food quality (pp. 201-277). Lancaster: Technomic Publishing.

13. Appendini, P., \& Hotchkiss, J. H. (2002). Review of antimicrobial food packaging. Innovative Food Science \& Emerging Technologies, 3(2), 113-126. http://dx.doi.org/10.1016/S14668564(02)00012-7.

14. Soares, N. F. F., Silva, W. A., Pires, A. C. S., Camiloto, G. P., \& Silva, O. S. (2009). Novos desenvolvimentos e aplicações em embalagens de alimentos. Revista Ceres, 56(4), 370-378. Retrieved in 07 March 2017, from http://www.ceres.ufv.br/ ojs/index.php/ceres/article/view/3438/1341

15. Sung, S. Y., Sin, L. T., Tee, T. T., Bee, S. T., Rahmat, A. R., Rahman, W. A. W. A., Tan, A. C., \& Vikhraman, M. (2013). Antimicrobial agents for food packaging applications. Trends in Food Science \& Technology, 33(2), 110-123. http://dx.doi. org/10.1016/j.tifs.2013.08.001.

16. Han, J. H. (2002). Protein-based edible films and coatings carrying antimicrobial agents. In A. Gennadios (Ed.), Proteinbased films and coatings (pp. 485-499). Boca Raton: CRC Press.

17. Tharanathan, R. N. (2003). Biodegradable films and composite coatings: past, present and future. Trends in Food Science \& Technology, 14(3), 71-78. http://dx.doi.org/10.1016/S09242244(02)00280-7.

18. Dorman, H. J. D., \& Deans, S. G. (2000). Antimicrobial agents from plants: antibacterial activity of plant volatile oils. Journal of Applied Microbiology, 88(2), 308-316. PMid:10736000. http://dx.doi.org/10.1046/j.1365-2672.2000.00969.x.

19. Baydar, H., Sağdiç, O., Özkan, G., \& Karadoğan, T. (2004). Antibacterial activity and composition of essential oils from Origanum, Thymbra and Satureja species with commercial importance in Turkey. Food Control, 15(3), 169-172. http:// dx.doi.org/10.1016/S0956-7135(03)00028-8.

20. Souza, E. L., Stamford, T. L. M., \& Lima, E. O. (2006). Sensitivity of spoiling and pathogen food-related bacteria to Origanum vulgare L. (Lamiaceae) essential oil. Brazilian Journal of Microbiology, 37(4), 527-532. http://dx.doi.org/10.1590/ S1517-83822006000400023.

21. Sivropoulou, A., Papanikolaou, E., Nikolaou, C., Kokkini, S., Lanaras, T., \& Arsenakis, M. (1996). Antimicrobial and cytotoxic activities of origanum essential oils. Journal of Agricultural and Food Chemistry, 44(5), 1202-1205. http:// dx.doi.org/10.1021/jf950540t.

22. Gyawali, R., \& Ibrahim, S. A. (2014). Natural products as antimicrobial agents. Food Control, 46, 412-429. http://dx.doi. org/10.1016/j.foodcont.2014.05.047

23. Sahin, F., Güllüce, M., Daferera, D., Sökmen, A., Sökmen, M., Polissiou, M., Agar, G., \& Özer, H. (2004). Biological activities of the essential oil and methanol extract of Origanum vulgare ssp. vulgare in the Eastern Anatolia region of Turkey. Food Control, 15(7), 549-557. http://dx.doi.org/10.1016/j. foodcont.2003.08.009. 
24. Pelissari, F. M., Grossmann, M. V. E., Yamashita, F., \& Pineda, E. A. G. (2009). Antimicrobial, mechanical, and barrier properties of cassava starch-chitosan films incorporated with oregano essential oil. Journal of Agricultural and Food Chemistry, 57(16), 7499-7504. PMid:19627142. http://dx.doi. org/10.1021/jf9002363.

25. Oussalah, M., Caillet, S., Salmiéri, S., Saucier, L., \& Lacroix, M. (2004). Antimicrobial and antioxidant effects of milk protein based film containing essential oils for the preservation of whole beef muscle. Journal of Agricultural and Food Chemistry, 52(18), 5598-5605. PMid:15373399. http://dx.doi. org/10.1021/jf049389q.

26. Yoshida, C. M. P., \& Antunes, A. J. (2009). Aplicação de filmes proteicos à base de soro de leite. Ciência e Tecnologia de Alimentos, 29(2), 420-430. http://dx.doi.org/10.1590/ S0101-20612009000200030.

27. American Society for Testing and Materials-ASTM. (1995). E96-95: standard test methods of water vapor transmission of materials. West Conshohocken: ASTM.

28. Gontard, N., Duchez, C., Cuq, J. L., \& Guilbert, S. (1994). Edible composite films of wheat and lipids: water vapour permeability and other physical properties. International Journal of Food Science \& Technology, 29(1), 39-50. http:// dx.doi.org/10.1111/j.1365-2621.1994.tb02045.x.

29. American Society for Testing and Materials -ASTM. (2010). D882-10: tensile properties of thin plastic sheeting. West Conshohocken: ASTM. Annual Book of ASTM Standards.
30. Bertan, L. C., Tanada-Palmu, P. S., Siani, A. C., \& Grosso, C. R. F. (2005). Effect of fatty acids and "Brazilian elemi" on composite films based on gelatin. Food Hydrocolloids, 19(1), 73-82. http://dx.doi.org/10.1016/j.foodhyd.2004.04.017.

31. Mei, Y., \& Zhao, Y. (2003). Barrier and mechanical properties of milk protein-based edible films containing nutraceuticals. Journal of Agricultural and Food Chemistry, 51(7), 1914-1918. PMid:12643651. http://dx.doi.org/10.1021/jf025944h.

32. McHugh, T. H., \& Krochta, J. M. (1994). Milk-protein-based edible films and coating. Food Technology, 48(1), 97-103.

33. Fairley, P., Monahan, F. J., German, B. B., \& Krochta, J. M. (1996). Mechanical properties and water vapor permeability of edible films from whey proteins isolate and $\mathrm{N}$-ethylamaleimidie or cysteine. Journal of Agricultural and Food Chemistry, 44(12), 3789-3792. http://dx.doi.org/10.1021/jf9601731.

34. Galietta, G., Di Gioia, L., Guilbert, S., \& Cuq, B. (1998). Mechanical and thermomechanical properties of films based on whey proteins as affected by plasticizer and crosslinking agents. Journal of Dairy Science, 81(12), 3123-3130. http:// dx.doi.org/10.3168/jds.S0022-0302(98)75877-1.

35. Bertan, L. C. (2003). Desenvolvimento e caracterização de filmes simples e compostos a base de gelatina, ácidos graxos e breu branco (Master's dissertation). Universidade Estadual de Campinas, Campinas.

Received: Mar: 07, 2016 Revised: July 26, 2016 Accepted: Dec. 13, 2016 